DOE/FETC-2000/1111

\title{
Demonstration of Selective Catalytic Reduction Technology to Control Nitrogen Oxide Emissions From High-Sulfur, Coal- Fired Boilers: A DOE Assessment
}

December 1999

U.S. Department of Energy Office of Fossil Energy

Federal Energy Technology Center

Morgantown, WV/Pittsburgh, PA

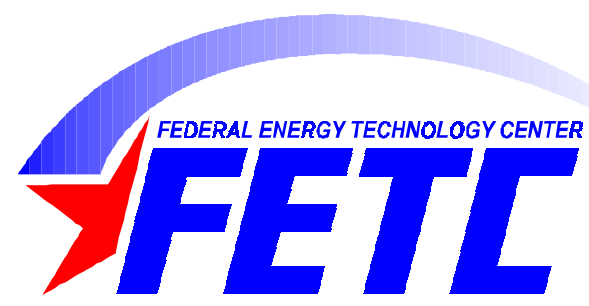




\section{Disclaimer}

This report was prepared as an account of work sponsored by an agency of the United States Government. Neither the United States Government nor any agency thereof, nor any of their employees, makes any warranty, express or implied, or assumes any legal liability or responsibility for the accuracy, completeness, or usefulness of any information, apparatus, product, or process disclosed, or represents that its use would not infringe privately owned rights. Reference herein to any specific commercial product, process, or service by trade name, trademark, manufacturer, or otherwise does not necessarily constitute or imply its endorsement, recommendation, or favoring by the United States Government or any agency thereof. The views and opinions of authors expressed herein do not necessarily state or reflect those of the United States Government or any agency thereof. 


\section{Contents}

\section{Page}

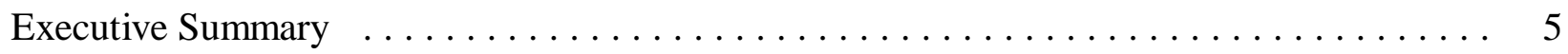

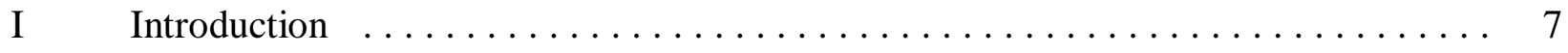

II Technical and Environmental Assessment $\ldots \ldots \ldots \ldots \ldots \ldots \ldots \ldots \ldots$

II.1 Promise of the Technology $\ldots \ldots \ldots \ldots \ldots \ldots \ldots \ldots \ldots \ldots \ldots$

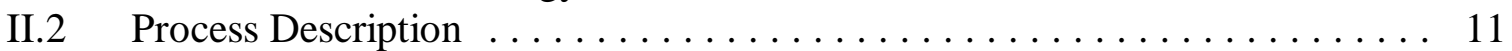

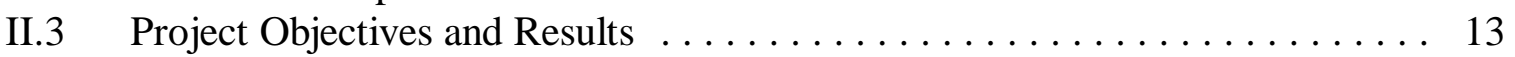

II.4 Environmental Performance $\ldots \ldots \ldots \ldots \ldots \ldots \ldots \ldots \ldots \ldots \ldots \ldots \ldots$

II.5 Post-Demonstration Achievements $\ldots \ldots \ldots \ldots \ldots \ldots \ldots \ldots \ldots \ldots 14$

III Operating Capabilities Demonstrated $\ldots \ldots \ldots \ldots \ldots \ldots \ldots \ldots \ldots \ldots \ldots \ldots$

III.1 Size of Unit Demonstrated $\ldots \ldots \ldots \ldots \ldots \ldots \ldots \ldots \ldots \ldots \ldots \ldots \ldots$

III.2 Performance Level Demonstrated $\ldots \ldots \ldots \ldots \ldots \ldots \ldots \ldots \ldots \ldots \ldots$

III.3 Major Operating and Design Variables Studied $\ldots \ldots \ldots \ldots \ldots \ldots \ldots$

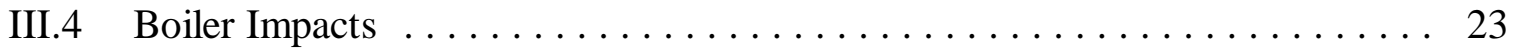

III.5 Commercialization of the Technology $\ldots \ldots \ldots \ldots \ldots \ldots \ldots \ldots \ldots 23$

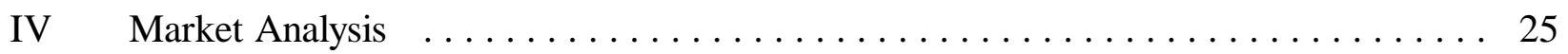

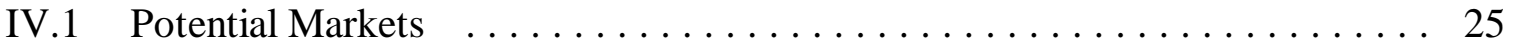

IV.2 Economic Assessment of Utility Boiler Applications f............. 25

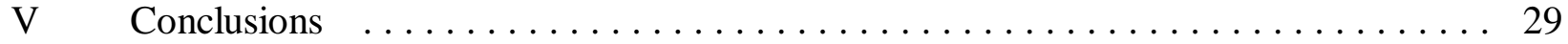

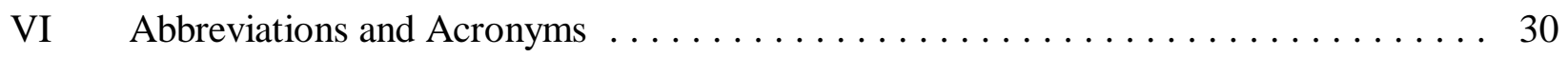

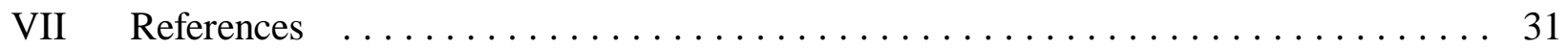

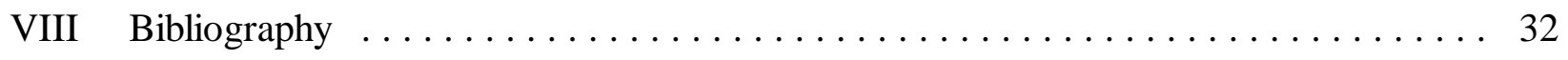




\section{List of Figures}

$\begin{array}{lll}\text { Figure } & \text { Page }\end{array}$

1 Block Flow Diagram of SCR Installation $\ldots \ldots \ldots \ldots \ldots \ldots \ldots$

2 Prototype SCR Demonstration Facility, Process Flow Diagram . . . . . . . . . . 13

$3 \quad \mathrm{~K} / \mathrm{K}_{\mathrm{o}}$ Versus Exposure Time $\ldots \ldots \ldots \ldots \ldots \ldots \ldots \ldots \ldots$

4 Ammonia Slip Versus Flow Rate $\ldots \ldots \ldots \ldots \ldots \ldots \ldots \ldots \ldots \ldots \ldots$

$5 \quad \mathrm{SO}_{2}$ Oxidation Versus Temperature $\ldots \ldots \ldots \ldots \ldots \ldots \ldots \ldots \ldots \ldots \ldots \ldots \ldots$

6 Ammonia Slip Versus $\mathrm{NH}_{3} / \mathrm{NO}_{\mathrm{X}}$ Ratio $\ldots \ldots \ldots \ldots \ldots \ldots \ldots \ldots \ldots \ldots$

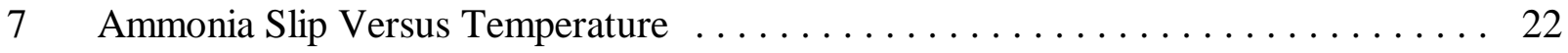

\section{List of Tables}

Table

Page

1 Title IV $\mathrm{NO}_{\mathrm{X}}$ Emission Limits $\ldots \ldots \ldots \ldots \ldots \ldots \ldots \ldots \ldots \ldots$

2 Worldwide Installations of SCR on Coal-Fired Utility Boilers, 1996 Data $\ldots . . . .10$

3 Properties of Coal Used in Plant Crist Tests $\ldots \ldots \ldots \ldots \ldots \ldots \ldots \ldots$

$4 \quad$ SCR Catalysts Tested at Plant Crist $\ldots \ldots \ldots \ldots \ldots \ldots \ldots \ldots \ldots \ldots \ldots$

5 Commercial SCR Installations on Coal-Fired Utility Boilers in the U.S. . . . . . . . 24

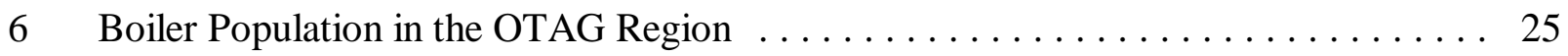

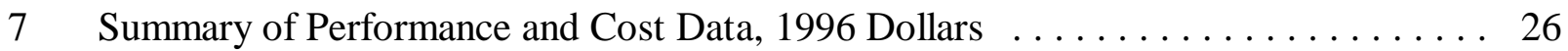

8 Effects of Variables on SCR Performance $\ldots \ldots \ldots \ldots \ldots \ldots \ldots \ldots$ 


\section{Executive Summary}

This document serves as the DOE post-project assessment of a project in Round 2 of the Clean Coal Technology (CCT) Program. The Selective Catalytic Reduction (SCR) Demonstration Project was conducted by Southern Company Services (Southern) beginning in June 1990. The operational testing was conducted between July 1993 and July 1995. Southern was a cofunder and Gulf Power Company's Plant Crist served as the host site. Other participants and cofunders were EPRI (formerly the Electric Power Research Institute) and Ontario Hydro. DOE provided 40 percent of the total project cost of $\$ 23$ million.

SCR technology consists of injecting ammonia $\left(\mathrm{NH}_{3}\right)$ into boiler flue gas and passing it through a catalyst bed where nitrogen oxides $\left(\mathrm{NO}_{\mathrm{X}}\right)$ and $\mathrm{NH}_{3}$ react to form nitrogen and water vapor.

The objectives of this project were to evaluate:

- $\quad$ Performance of a wide variety of SCR catalyst compositions, geometries, and manufacturing methods at typical U.S. high-sulfur coal-fired utility operating conditions.

- $\quad$ Catalyst resistance to poisoning by trace metal species present in U.S. coals but not present, or present at much lower concentrations, in fuels from other countries.

- $\quad$ Effects on the balance-of-plant equipment from sulfur compounds formed by reactions between sulfur dioxide $\left(\mathrm{SO}_{2}\right)$, sulfur trioxide $\left(\mathrm{SO}_{3}\right)$, and $\mathrm{NH}_{3}$ (e.g., plugging and corrosion of downstream equipment).

The catalysts were tested over a 2-year period, during which they were exposed to flue gas from a coal-fired boiler at Plant Crist under commercial installation conditions. Six catalyst suppliers (two U.S., two European, and two Japanese) provided eight different catalysts.

The SCR demonstration project successfully met all objectives. All eight catalysts met design specifications, providing at least 80 percent $\mathrm{NO}_{\mathrm{X}}$ removal at an $\mathrm{NH}_{3}$ slip of 5 ppm or less. Although the catalysts varied somewhat in operating characteristics, such as activity and pressure drop, no one catalyst was found to be superior. Both plate and honeycomb catalysts performed satisfactorily. Catalyst deactivation proceeded as expected, based on European and Japanese experience. Although the Plant Crist test results indicate that no catastrophic deactivation would be expected, catalyst replacement frequency for high-sulfur U.S. coals remains uncertain.

The oxidation rate of $\mathrm{SO}_{2}$ to $\mathrm{SO}_{3}$ varied significantly among the catalysts tested. The amounts of ammonium sulfate and ammonium bisulfate formed were sufficient to require periodic washing of the air preheaters, and there was evidence for deposition of these salts on the catalysts. Overall, the pressure drop across the catalyst beds over time was stable, indicating that the sootblowing procedures used in the test program were satisfactory. Performance comparisons 
between high-dust and low-dust reactor configurations were inconclusive because of problems associated with the design of the low-dust reactor.

Southern also performed an economic study of implementing SCR technology. The basecase economics were estimated for an SCR unit installed in a new power plant, using a projected process design that incorporates improvements based on experience gained from the SCR demonstration project. The boiler is assumed to be either a wall-fired or a tangentially fired unit, equipped with low- $\mathrm{NO}_{\mathrm{X}}$ burners, and burning $2.5 \mathrm{wt} \%$ sulfur coal. Design $\mathrm{NO}_{\mathrm{X}}$ concentration at the reactor inlet is $0.35 \mathrm{lb} / 10^{6} \mathrm{Btu}$. $\mathrm{NO}_{\mathrm{X}}$ reduction is assumed to be 60 percent, giving an outlet concentration of $0.14 \mathrm{lb} / 10^{6} \mathrm{Btu}$, with a design $\mathrm{NH}_{3}$ slip of $5 \mathrm{ppm}$.

Based on these assumptions, the capital cost ranges from $\$ 45 / \mathrm{kW}$ at a capacity of 700 MWe to $\$ 61 / \mathrm{kW}$ at $125 \mathrm{MWe}$. Levelized cost on a current dollar basis range from $\$ 2,165 /$ ton of $\mathrm{NO}_{\mathrm{X}}$ removed for a $700 \mathrm{MWe}$ plant to $\$ 2,811 /$ ton at $125 \mathrm{MWe}$.

Six commercial SCR units have been installed and are operating on low- and mediumsulfur U.S. coals. Because SCR is applicable to almost any kind of boiler, many utilities will likely consider SCR technology in their compliance planning efforts, especially in light of increasingly stringent limitations on $\mathrm{NO}_{\mathrm{X}}$ emissions. 


\section{Introduction}

The goal of the U.S. Department of Energy (DOE) Clean Coal Technology (CCT) program is to furnish the energy marketplace with a number of advanced, more efficient, and environmentally responsible coal utilization technologies through demonstration projects. These projects seek to establish the commercial feasibility of the most promising advanced coal technologies that have developed beyond the proof-of-concept stage.

This document serves as a DOE post-project assessment of a project selected in CCT Round 2. The project is described in the report Demonstration of Selective Catalytic Reduction (SCR) Technology for the Control of Nitrogen Oxide $\left(N O_{X}\right)$ Emissions from High-Sulfur, CoalFired Boilers (Southern Company Services 1990).

In June 1990, Southern Company Services (Southern) entered into a cooperative agreement to conduct the study. Southern was a cofunder and served as the host at Gulf Power Company's Plant Crist. Other participants and cofunders were EPRI (formerly the Electric Power Research Institute) and Ontario Hydro. DOE provided 40 percent of the total project cost of \$23 million.

The long-term operation phase of the demonstration was started in July 1993 and was completed in July 1995. This independent evaluation is based primarily on information from Southern's Final Report (Southern Company Services 1996).

The SCR process consists of injecting ammonia $\left(\mathrm{NH}_{3}\right)$ into boiler flue gas and passing the flue gas through a catalyst bed where the $\mathrm{NO}_{\mathrm{X}}$ and $\mathrm{NH}_{3}$ react to form nitrogen and water vapor.

The objectives of the demonstration project were to investigate:

- $\quad$ Performance of a wide variety of SCR catalyst compositions, geometries, and manufacturing methods at typical U.S. high-sulfur coal-fired utility operating conditions.

- $\quad$ Catalyst resistance to poisoning by trace metal species present in U.S. coals but not present, or present at much lower concentrations, in fuels from other countries.

- $\quad$ Effects on the balance-of-plant equipment from sulfur compounds formed by reactions between sulfur dioxide $\left(\mathrm{SO}_{2}\right)$, sulfur trioxide $\left(\mathrm{SO}_{3}\right)$, and $\mathrm{NH}_{3}$ (e.g., plugging and corrosion of downstream equipment).

The Clean Air Act, initially promulgated in 1970, established New Source Performance Standards (NSPS) for emissions of $\mathrm{SO}_{2}, \mathrm{NO}_{\mathrm{X}}$, and particulates, among other pollutants, from stationary coal-fired power plants. These regulations were made more stringent in the Clean Air Act Amendments (CAAA) of 1990. The SCR process is one way to meet the $\mathrm{NO}_{\mathrm{X}}$ emissions requirements of the CAAA. 


\section{Technical and Environmental Assessment}

\section{II.1 Promise of the Technology}

This project was undertaken to evaluate the performance and economics of the SCR process for removing $\mathrm{NO}_{\mathrm{X}}$ from the flue gas of boilers fired with U.S. high-sulfur coals. A major advantage of SCR is that the reaction products, nitrogen and water, are innocuous compounds already present in air. The SCR process was initially developed in the United States. The process is widely used in Japan and Europe, including numerous installations on coal-burning power plants. Technical uncertainties associated with applying SCR to plants burning U.S. high-sulfur coals primarily involved the danger of forming excessive amounts of ammonia-sulfur compounds with the attendant plugging and corrosion of downstream equipment. There was also concern over the presence of trace metals such as arsenic, since they can lead to catalyst deactivation.

The SCR demonstration project at Plant Crist was designed to evaluate the performance and cost of SCR technology under typical boiler conditions in the United States. If successful, the process could provide a means of meeting increasingly more stringent $\mathrm{NO}_{\mathrm{X}}$ emission regulations for U.S. coal-burning power plants.

The Clean Air Act was originally passed in 1967. It was amended in 1970, 1977, and most recently in 1990. The CAAA of 1990 authorized the U.S. Environmental Protection Agency (EPA) to establish emissions standards for a number of atmospheric pollutants, revising and expanding standards for emissions of $\mathrm{SO}_{2}$ and $\mathrm{NO}_{\mathrm{X}}$. The CAAA mandates updating of the emissions standards every 5 years.

\section{$\mathrm{NO}_{\mathrm{x}}$ Emissions Regulations}

Two major portions of the CAAA relevant to $\mathrm{NO}_{\mathrm{X}}$ control are Title I and Title IV. Title I establishes National Ambient Air Quality Standards (NAAQS) for six criteria pollutants, including ozone. Title IV addresses controls for specific types of boilers, including coal-fired units. Title IV is often referred to as the Acid Rain Program.

Title IV uses a two-phase $\mathrm{NO}_{\mathrm{x}}$ control strategy. Phase I, which had an implementation deadline of January 1, 1996, established regulations for 256 Group 1 boilers: dry-bottom, wallfired boilers, and tangentially fired (T-fired) boilers. In Phase II, which requires compliance by January 1, 2000, lower emission limits are set for Group 1 boilers, and limits are set for 145 Group 2 boilers, which include cell-burners, cyclones, wet-bottom, wall-fired boilers, and other types of coal-fired boilers. In addition, another 607 wall-fired and T-fired boilers must meet the applicable Phase II limits. The final emission limits under Title IV, promulgated in February 1998, are shown in Table 1. 
Table 1. Title IV $\mathrm{NO}_{\mathrm{x}}$ Emissions Limits

$\left(\mathrm{lb} / 10^{6} \mathrm{Btu}\right)$

\begin{tabular}{|r|c|c|}
\hline Implementation Deadline & Phase I, January 1, 1996 & Phase II, January 2, 2000 \\
\hline $\begin{array}{r}\text { Group 1 Boilers } \\
\text { Dry Bottom Wall-Fired }\end{array}$ & 0.50 & 0.46 \\
\hline Tangentially Fired & 0.45 & 0.40 \\
\hline $\begin{array}{r}\text { Group 2 Boilers } \\
\text { Wet Bottom Wall-Fired } \\
>\text { 65 MWe }\end{array}$ & NA & 0.84 \\
\hline $\begin{array}{r}\text { Cyclone-Fired } \\
>155 \text { MWe }\end{array}$ & NA & 0.86 \\
\hline Vertically Fired & NA & 0.80 \\
\hline Cell Burner & NA & 0.68 \\
\hline Fluidized Bed & NA & Exempt \\
\hline Stoker & NA & Exempt \\
\hline
\end{tabular}

NA = Not applicable

When $\mathrm{NO}_{\mathrm{X}}$ and volatile organic compounds (VOCs) enter the atmosphere, they react in the presence of sunlight to form ground-level ozone, which is the major ingredient of smog. The federal Title $\mathrm{I} \mathrm{NO}_{\mathrm{X}}$ requirements are as follows:

- $\quad$ Existing major stationary sources must apply reasonably available control technologies (RACT)

- New or modified major stationary sources must offset their new emissions and install controls representing the best available control technology (BACT)

- $\quad$ Each state must include ozone control in its State Implementation Plan (SIP).

The current NAAQS for ozone is $0.12 \mathrm{ppm}$ (1-hour average). At this level, many largeand medium-size urban areas are classified as nonattainment and many power plants are within these nonattainment areas. Furthermore, the Northeast Ozone Transport Region (NOTR) is a 13state area that is considered nonattainment with respect to ozone.

EPA proposed more stringent NAAQS for ozone: $0.08 \mathrm{ppm}$ (8-hour average). An area would be considered nonattainment when the third highest daily maximum 8-hour concentration, averaged over 3 years, is above $0.08 \mathrm{ppm}$. EPA is also seeking comment on a standard of 0.07 ppm. 
The primary technology currently used in utility boilers for $\mathrm{NO}_{\mathrm{X}}$ reduction is low $\mathrm{NO}_{\mathrm{X}}$ burners (LNBs), which have generally proven adequate to meet Title IV emissions requirements. Field experience with LNBs in the CCT Program provided the data required to establish the current regulations. However, the lower $\mathrm{NO}_{\mathrm{X}}$ target levels being considered under Title I may force utilities subject to the most stringent requirements to install LNBs combined with SCR, or alternatively, SCR alone.

\section{History of the SCR Process}

Selective catalytic reduction of $\mathrm{NO}_{\mathrm{X}}$ using $\mathrm{NH}_{3}$ as the reducing gas was patented in the U.S. by Englehard Corporation in 1957. The original catalysts, employing platinum or platinum group metals, were unsatisfactory because of the need to operate in a temperature range in which explosive ammonium nitrate forms. Other base metal catalysts were found to have low activity. Research done in Japan in response to severe environmental regulations in that country led to the development of vanadium/titanium catalysts, which have proved successful. This combination forms the basis of current SCR catalyst technology.

In addition to Japan, several countries in Western Europe have enacted stringent $\mathrm{NO}_{\mathrm{X}}$ emission regulations that essentially mandate the installation of SCR, and extensive catalyst development work has been done, especially in Germany. As a result, SCR has been used on numerous boilers in Europe. Furthermore, encouraged in part by the initial success of the SCR test program at Plant Crist, there are now six commercial installations of SCR on coal-burning power plants in the U.S. Worldwide installations of SCR on coal-fired utility boilers are summarized in Table 2.

Table 2. Worldwide Installations of SCR on Coal-Fired Utility Boilers, 1996 Data

\begin{tabular}{|l|c|}
\hline Country/Region & Capacity, MWe \\
\hline Austria & 1,200 \\
\hline Germany & 33,000 \\
\hline Japan & 7,700 \\
\hline Netherlands & 1,000 \\
\hline Scandinavia & 1,100 \\
\hline United States & 2,000 \\
\hline Total & 46,000 \\
\hline
\end{tabular}




\section{II.2 Process Description}

Figure 1 is a schematic that illustrates SCR process.

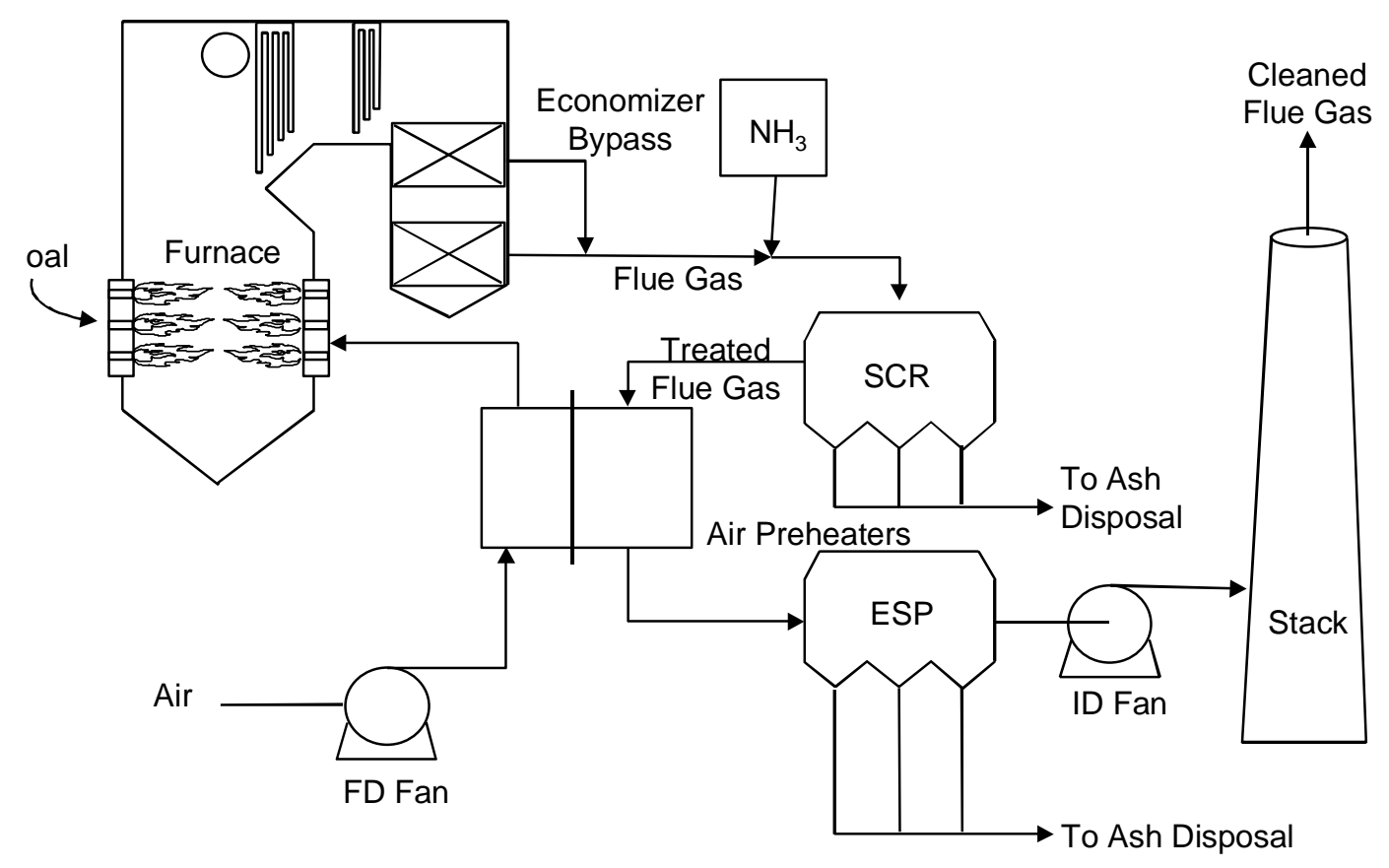

Figure 1. Block Flow Diagram of SCR Installation

$\mathrm{NO}_{\mathrm{X}}$, which consists primarily of $\mathrm{NO}$ and $\mathrm{NO}_{2}$, is converted to nitrogen by reacting with ammonia $\left(\mathrm{NH}_{3}\right)$ in the presence of oxygen, according to the following equations:

$$
\begin{aligned}
& 4 \mathrm{NO}+4 \mathrm{NH}_{3}+\mathrm{O}_{2} \Rightarrow 4 \mathrm{~N}_{2}+6 \mathrm{H}_{2} \mathrm{O} \\
& 2 \mathrm{NO}_{2}+4 \mathrm{NH}_{3}+\mathrm{O}_{2} \Rightarrow 3 \mathrm{~N}_{2}+6 \mathrm{H}_{2} \mathrm{O}
\end{aligned}
$$

Since the $\mathrm{NO}_{\mathrm{X}}$ contained in flue gas derived from coal-fired boilers is primarily $\mathrm{NO}$, the first reaction predominates. Sulfur present in the coal is oxidized to $\mathrm{SO}_{2}$ in the boiler. A small percentage of the $\mathrm{SO}_{2}$ is also oxidized to $\mathrm{SO}_{3}$ in the boiler according to the following equation:

$$
\mathrm{SO}_{2}+1 / 2 \mathrm{O}_{2} \Rightarrow \mathrm{SO}_{3}
$$

Thus, $\mathrm{SO}_{3}$ levels at the boiler exit will typically increase as sulfur content of the coal increases. In addition, a portion of the $\mathrm{SO}_{2}$ is oxidized over the SCR catalyst by the same equation.

The following side reactions produce undesirable by-products: ammonium sulfate, $\left(\mathrm{NH}_{4}\right)_{2} \mathrm{SO}_{4}$, and ammonium bisulfate, $\mathrm{NH}_{4} \mathrm{HSO}_{4}$. 


$$
\begin{array}{ccc}
2 \mathrm{NH}_{3}+\mathrm{SO}_{3}+\mathrm{H}_{2} \mathrm{O} & \Rightarrow & \left(\mathrm{NH}_{4}\right)_{2} \mathrm{SO}_{4} \\
\mathrm{NH}_{3}+\mathrm{SO}_{3}+\mathrm{H}_{2} \mathrm{O} & \Rightarrow & \mathrm{NH}_{4} \mathrm{HSO}_{4}
\end{array}
$$

Because of these side reactions, it is essential to minimize the amount of unreacted $\mathrm{NH}_{3}$ in the flue gas downstream of the SCR reactor. This quantity is referred to as $\mathrm{NH}_{3}$ slip and, in general, must be held below $5 \mathrm{ppm}$ and preferably 2 to $3 \mathrm{ppm}$. As indicated, the $\mathrm{NH}_{3}$ slip reacts with small quantities of $\mathrm{SO}_{3}$ in the $\mathrm{SCR}$ reactor exit to form $\left(\mathrm{NH}_{4}\right)_{2} \mathrm{SO}_{4}$ and $\mathrm{NH}_{4} \mathrm{HSO}_{4}$, which can plug and corrode downstream equipment. This is a greater problem with high-sulfur coals, because of the higher $\mathrm{SO}_{3}$ levels that result from greater quantities of fuel-generated $\mathrm{SO}_{3}$ in the boiler and further oxidation of $\mathrm{SO}_{2}$ in the SCR reactor.

Since SCR catalysts are relatively expensive, it is essential to maximize space velocity and thus minimize catalyst volume for a given application. At the same time, the rate of oxidation of $\mathrm{SO}_{2}$ to $\mathrm{SO}_{3}$ must be minimized, which is more temperature sensitive than the SCR reaction. The optimum operating temperature for the SCR process using titanium and vanadium oxide catalysts is about 650 to $750{ }^{\circ} \mathrm{F}$. Some installations use an economizer bypass to maintain the desired flue gas temperature in the reactors during low load operation.

SCR systems can be installed at any of three locations in a power plant:

- $\quad$ Upstream of the air preheater (APH) and electrostatic precipitator (ESP), referred to as hot-side, high-dust.

- Upstream of the APH and downstream of the ESP, hot-side, low-dust.

- $\quad$ Downstream of the APH and ESP, cold-side, low-dust.

In the Plant Crist tests, which operated on a slipstream from the power plant flue gas, each reactor was located upstream of the APH; thus, these were hot-side installations. Seven of the eight reactors were also high-dust installations. The Plant Crist installation is shown in Figure 2.

In commercial practice, most SCR reactors are hot-side, high-dust installations. This location is preferred because it obviates the need to reheat the flue gas to reaction temperature, thereby minimizing loss of thermal efficiency.

SCR catalysts are generally made of a ceramic material that is a mixture of substrate (titanium oxide) and active components (oxides of vanadium and, in some cases, tungsten). The two leading shapes of SCR catalyst used today are honeycomb and plate. Both types were tested at Plant Crist. The honeycomb form usually is an extruded ceramic with the catalyst either incorporated throughout the structure (homogeneous) or coated on the substrate. In plate geometry, the support material is generally coated with a catalyst. When processing flue gas that contains dust, the reactors are typically vertical, with a down flow of flue gas. The catalyst is typically arranged in a series of two to four beds or layers. For systems operating at about 80percent $\mathrm{NO}_{\mathrm{X}}$ reduction, it is common to use three or four layers, and to include provisions for an additional layer, which is not initially installed. This arrangement permits optimization of the catalyst 


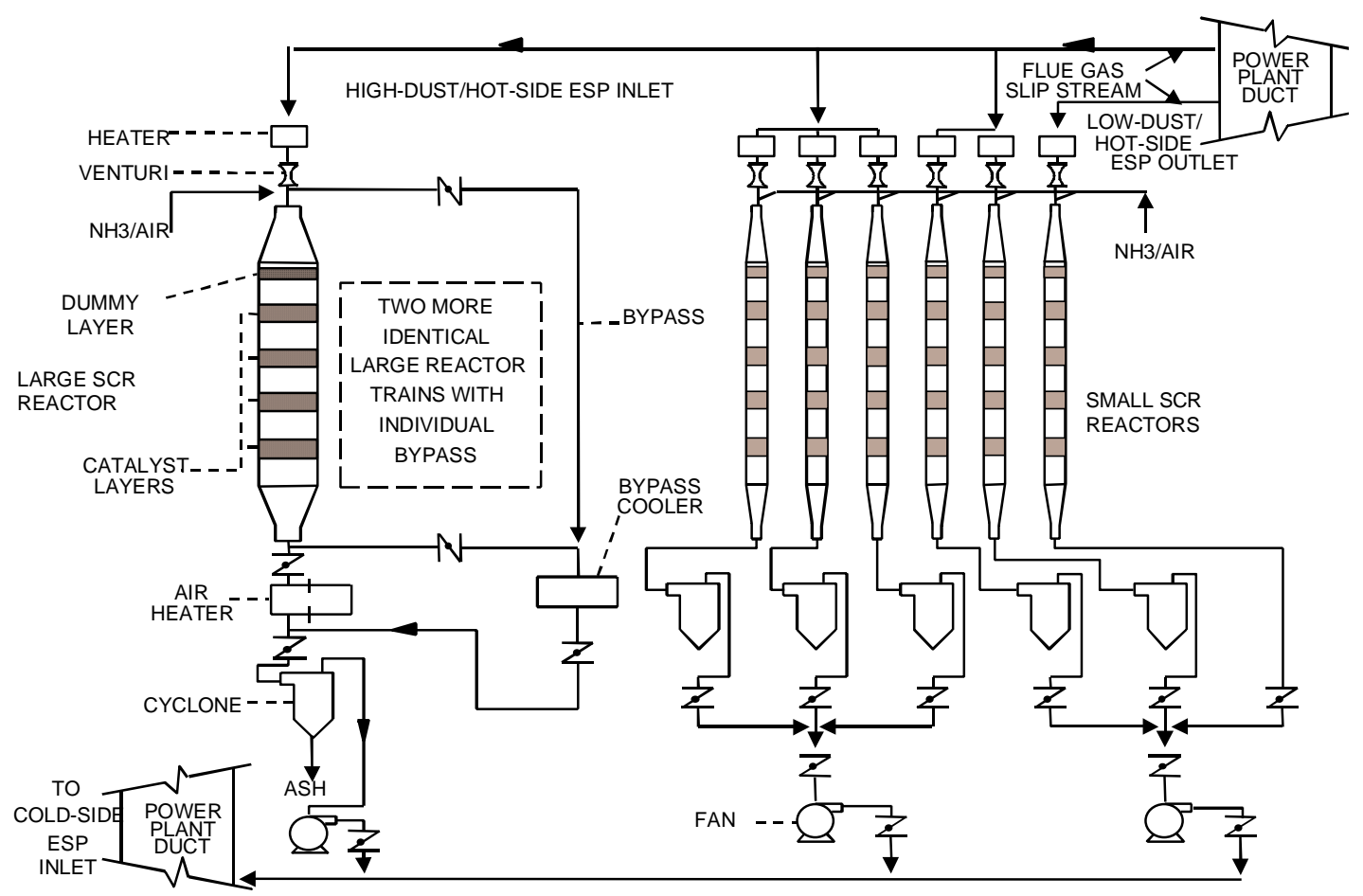

Figure 2. Prototype SCR Demonstration Facility, Process Flow Diagram

management plan to allow for catalyst deactivation, additional $\mathrm{NO}_{\mathrm{X}}$ reduction requirements, or both in a more cost effective manner.

As the catalyst activity declines, additional catalyst is installed in the available spaces in the reactor. As deactivation continues, the catalyst is replaced on a rotating basis, one layer at a time, starting with the top. This strategy results in maximum catalyst utilization. The catalyst is subjected to periodic soot-blowing to remove deposits, using steam as the cleaning agent.

\section{II.3 Project Objectives and Results}

The goal of this project was to evaluate SCR technology for reducing $\mathrm{NO}_{\mathrm{X}}$ emissions from utility boilers burning U.S. coals. The project was designed to confirm pilot-plant results and to develop scaleup procedures necessary for commercial application of the technology, as well as to resolve those technical issues that could not be adequately addressed in an engineering study.

The objectives of this project were to investigate:

- $\quad$ Performance of a wide variety of SCR catalyst compositions, geometries, and manufacturing methods at typical U.S. high-sulfur coal-fired utility operating conditions.

- $\quad$ Catalyst resistance to poisoning by trace metal species present in high-sulfur U.S. coals but not present, or present at much lower concentrations, in fuels from other countries. 
- $\quad$ Effects on the balance-of-plant equipment from sulfur compounds formed by reactions between $\mathrm{SO}_{2}, \mathrm{SO}_{3}$, and $\mathrm{NH}_{3}$ (e.g., plugging and corrosion of downstream equipment)

Six catalyst suppliers (two U.S., two European, and two Japanese) provided eight catalysts with various chemical compositions and shapes (plate or honeycomb). Catalyst suppliers were given latitude in designing their catalyst offerings to meet a minimum of 80-percent $\mathrm{NO}_{\mathrm{X}}$ reduction for long-term baseline conditions. All catalysts performed well, yielding $\mathrm{NO}_{\mathrm{X}}$ removal rates of 80 percent or better with acceptable $\mathrm{NH}_{3}$ slip.

Higher rates of $\mathrm{NO}_{\mathrm{X}}$ removal, up to 90 percent or more, may be achievable for some units, depending on plant characteristics, but for most commercial applications, the $\mathrm{NO}_{\mathrm{X}}$ removal rate will likely be limited to about 80 percent. Careful system design and process control are required to avoid excessive $\mathrm{NH}_{3}$ slip, especially at the higher conversion levels.

\section{II.4 Environmental Performance}

The environmental impact of the SCR demonstration project is covered in a separate report (Radian Corporation 1996). The project had only a minor effect on air quality at Plant Crist, because only a relatively small flue gas slipstream was treated. Likewise, there was no detectable impact on water quality in the ash pond discharge stream. However, the environmental impacts of the technology studied in the test program are significant. SCR has been shown to provide high levels of $\mathrm{NO}_{\mathrm{X}}$ removal with minimal $\mathrm{NH}_{3}$ slip.

\section{II.5 Post-Demonstration Achievements}

SCR units are being operated in six commercial coal-fired power plants in the United States, on coals ranging in sulfur content from about 0.8 to $2.0 \mathrm{wt} \%$. Data from the demonstration project and the subsequent commercial applications have shown that SCR can routinely achieve the required levels of $\mathrm{NO}_{\mathrm{X}}$ reduction to comply with present and anticipated environmental regulations. 


\section{Operating Capabilities Demonstrated}

\section{III.1 Size of Unit Demonstrated}

The demonstration project was conducted at Gulf Power's Plant Crist, located near Pensacola, Florida. Plant Crist consists of seven fossil fueled generating units. Units 1, 2, and 3 are small gas- and oil-fired boilers, and Units 4 through 7 are coal-fired. The SCR test facility was built in and around the duct work on Unit 5. This unit is a tangentially fired, dry-bottom boiler, rated at $75 \mathrm{MWe}$ (gross), built by Combustion Engineering and placed into operation in 1961. The unit is equipped with hot-side and cold-side ESPs for particulate control.

As shown in Figure 2, the individual SCR reactors operated on a slipstream taken from the flue gas of Unit 5. There were three 2.5-MWe equivalent reactors and six 0.20-MWe equivalent reactors, each containing a different catalyst for side-to-side performance comparisons. Eight of the nine reactors were designed to treat the flue gas containing full particulate loading (high-dust), extracted from the inlet duct of the hot-side ESP. One small reactor was designed to treat flue gas extracted from the hot-side ESP outlet (low-dust). Because of a reactor design problem, it was not possible to fully evaluate the differences in performance between the single low-dust reactor and the high-dust units.

Each reactor train was equipped with an electric duct heater to independently control flue gas temperature and a venturi meter to measure the flue-gas flow rate. An economizer bypass line maintained a minimum flue gas temperature of $620{ }^{\circ} \mathrm{F}$ to the high dust reactors. Anhydrous $\mathrm{NH}_{3}$ was independently metered to a stream of heated dilution air and was injected by nozzles into the flue gas upstream of each SCR reactor. The flue gas containing $\mathrm{NH}_{3}$ passed through the reactors, each of which had the capacity to contain up to four catalyst layers.

For each of the larger reactor trains, the flue gas exiting the reactor entered a specially modified pilot-scale APH, each of different design. The modified APHs were used to better simulate full-scale APHs and thus improve the extrapolation of results to commercial scale. The APHs were incorporated in the project to evaluate the effects of the SCR on APH deposit formation and the effects of the deposits on APH performance and operation.

All reactor trains except the low-dust train had a cyclone downstream of the SCR reactor to protect the induced draft fans from particulates. The exhausts from all of the SCR reactors were combined into a single manifold and reinjected into the host boiler's flue gas stream ahead of the cold-side ESP. The preheated air streams from the APH on the larger reactors were also combined into a single manifold and returned to the host boiler draft system at the existing host APH outlet. All particulate matter removed from the test facility was combined with ash from the host unit's ESP and sent to ash disposal.

The test facility examined the performance of eight SCR catalysts (one reactor was idled because of the withdrawal of a project participant), differing in chemical makeup and physical 
form. Each catalyst supplier was given great latitude in designing the catalyst offering, provided it met the following requirements:

- $\quad$ Catalyst baskets that match predetermined reactor dimensions.

- A maximum of four catalyst layers.

- $\quad$ A maximum baseline $\mathrm{SO}_{2}$ oxidation rate of 0.75 percent.

- A maximum baseline slip of 5 ppm.

- A minimum 80-percent $\mathrm{NO}_{\mathrm{X}}$ reduction at baseline conditions.

- A 2-year life while meeting the above performance criteria.

Full-scale demonstration of SCR technology was not required, since the major issues to be addressed were questions of chemistry, which could be adequately investigated using a slipstream facility. A full-scale facility would have been unnecessarily expensive while providing little additional technical information. However, the catalyst modules used in the reactors were fullscale versions of the catalysts used commercially in Europe and Japan. The test units were designed to ensure that the flue gas slipstreams were fully representative in terms of gaseous and solid species and that the catalyst modules were exposed to flue gas conditions identical to those experienced in full-scale installations. In general, the performance of fixed-bed catalytic reactors can readily be scaled up.

The tests were conducted on flue gas derived primarily from burning Illinois No. 6 coal, a typical midwestern high-sulfur (2.3 percent sulfur) coal widely used for power generation. Coal properties are given in Table 3.

Table 3. Properties of Coal Used in Plant Crist Tests

(Coal source: Illinois No. 6 Bituminous)

Proximate Analysis, wt\% (as received)
\begin{tabular}{|l|c|}
\hline Fixed Carbon & 47.65 \\
\hline Volatile Matter & 34.16 \\
\hline Moisture & 9.80 \\
\hline Ash & 8.39 \\
\hline \hline Total & $\mathbf{1 0 0 . 0 0}$ \\
\hline \hline HHV , Btu/lb & 12,500 \\
\hline
\end{tabular}

$\mathrm{HHV}=$ higher heating value

Ultimate Analysis, wt\% (as received)

\begin{tabular}{|l|l|}
\hline Carbon & 67.48 \\
\hline Hydrogen & 4.51 \\
\hline Nitrogen & 1.43 \\
\hline Sulfur & 2.33 \\
\hline Chlorine & 0.14 \\
\hline Oxygen & 5.92 \\
\hline Ash & 8.39 \\
\hline Water & 9.80 \\
\hline \hline Total & $\mathbf{1 0 0 . 0 0}$ \\
\hline
\end{tabular}




\section{III.2 Performance Level Demonstrated}

Over the 2-year test period, operating experience with individual catalysts ranged from 4,000 to 13,000 hours. Parametric testing was conducted every 4 to 6 months. Catalysts were provided initially by three U.S. suppliers (Englehard, Grace, and Cormetech), two European suppliers (Haldor Topsoe and Siemens), and two Japanese suppliers (Hitachi Zosen and Nippon Shokubai). Englehard subsequently withdrew from the project, and its low-dust catalyst was replaced by one of Cormetech's available low-dust catalysts. The catalysts tested in this project are listed in Table 4.

Table 4. SCR Catalysts Tested at Plant Crist

\begin{tabular}{|c|l|l|l|l|l|}
\hline Reactor & \multicolumn{1}{|c|}{ Catalyst Supplier } & $\begin{array}{c}\text { Reactor } \\
\text { Size }\end{array}$ & $\begin{array}{c}\text { Dust } \\
\text { Level }\end{array}$ & Composition & $\begin{array}{c}\text { Catalyst } \\
\text { Configuration }\end{array}$ \\
\hline $\mathbf{A}$ & $\begin{array}{l}\text { W.R. Grace } \\
\text { (Noxeram) }\end{array}$ & Large & High & V-W/Ti & Honeycomb \\
\hline B & $\begin{array}{l}\text { Nippon Shokubai } \\
\text { K.K. }\end{array}$ & Large & High & V-W/Ti-Si & Honeycomb \\
\hline $\mathbf{C}$ & Siemens AG & Large & High & V/Ti & Plate \\
\hline $\mathbf{D}$ & $\begin{array}{l}\text { W.R. Grace } \\
\text { (Synox) }\end{array}$ & Small & High & V/Ti-Si & Honeycomb \\
\hline $\mathbf{E}$ & Cormetech & Small & High & V-W/Ti & Honeycomb \\
\hline F & Haldor Topsoe & Small & High & V/Ti & Plate \\
\hline $\mathbf{G}$ & Hitachi Zosen & Small & High & V/Ti & Plate \\
\hline J & Cormetech & Small & Low & V-W/Ti & Honeycomb \\
\hline
\end{tabular}

All of the catalysts performed well in both parametric and long-term testing, achieving at least 80-percent $\mathrm{NO}_{\mathrm{X}}$ removal with a maximum $\mathrm{NH}_{3}$ slip of $5 \mathrm{ppm}$. Although the catalysts varied somewhat in operating characteristics, such as activity and pressure drop, no one catalyst was found to be superior. Catalyst deactivation proceeded as expected, based on European and Japanese experience. Extrapolating the test data to 16,000 hours suggests an average decrease in activity of about 20 percent, although in practice this decrease could range from 10 to 30 percent.

Although no catastrophic deactivation effects could be attributed to the use of high-sulfur U.S. coals, catalyst replacement frequency remains uncertain. No detrimental effects of trace metals such as arsenic were detected. However, the accumulation of trace metals on the surface of the catalysts was clearly evident in the laboratory tests. 
Both plate and honeycomb catalysts performed satisfactorily. A major difference between these catalyst configurations is pressure drop, which must be taken into account in designing commercial SCR installations.

The overall stability of the pressure drop across the catalyst beds over time indicated that the soot-blowing procedures used in the test program were satisfactory. Performance comparisons between high-dust and low-dust reactor configurations were inconclusive because of problems associated with the design of the low-dust reactor. There was significant variation in the rate of oxidation of $\mathrm{SO}_{2}$ to $\mathrm{SO}_{3}$ among the catalysts tested. The amounts of $\left(\mathrm{NH}_{4}\right)_{2} \mathrm{SO}_{4}$ and $\mathrm{NH}_{4} \mathrm{HSO}_{4}$ formed were sufficient to result in corrosion and plugging of the APHs downstream of the SCR reactors, requiring periodic washing and indicating the need to choose appropriate materials of construction for APHs for commercial SCR installations.

\section{III.3 Major Operating and Design Variables Studied}

Testing consisted of long-term studies of catalyst deactivation as well as parametric tests to investigate the effects of operating variables. The purpose of the parametric tests was to study the effects of several variables, including reactor operating temperature, $\mathrm{NH}_{3} / \mathrm{NO}_{\mathrm{X}}$ molar ratio, and space velocity.

\section{Long-Term Testing of Catalyst Deactivation}

The results of the long-term catalyst tests are expressed in terms of the decrease in activity over time. The rate constant, $\mathrm{k}$, is defined in the following kinetic equations from S.M. Cho of Foster Wheeler (Cho 1994):

$$
\begin{aligned}
& \mathrm{k} / \mathrm{SV}=-\ln (1-\mathrm{x} / \mathrm{r}), \text { and } \\
& \mathrm{s}=(\mathrm{r}-\mathrm{x}) \mathrm{N}_{\mathrm{o}} \text { or } \mathrm{r}=\mathrm{x}+\mathrm{s} / \mathrm{N}_{\mathrm{o}},
\end{aligned}
$$

where $\mathrm{k}=$ rate constant; $\mathrm{SV}=$ space velocity; $\mathrm{x}=$ fractional conversion of $\mathrm{NO}_{\mathrm{X}} ; \mathrm{r}=$ molar ratio of $\mathrm{NH}_{3}$ to $\mathrm{NO}_{\mathrm{X}}$ at reactor inlet; $\mathrm{s}=\mathrm{NH}_{3}$ slip; and $\mathrm{N}_{\mathrm{o}}=\mathrm{NO}_{\mathrm{X}}$ concentration at the reactor inlet.

These equations assume that the SCR reaction is first order with respect to $\mathrm{NO}_{\mathrm{X}}$ or $\mathrm{NH}_{3}$. Work by Rao, McIlvried, and Mann (1994) and Baldwin, Smith and others (1995) has shown that the process can be better represented by a modified Langmuir-Hinshelwood relationship, as follows:

$$
\mathrm{k} / \mathrm{SV}=-\ln (1-\mathrm{x} / \mathrm{r})+\ln [(1-\mathrm{x}) /(1-\mathrm{x} / \mathrm{r})] / \mathrm{KN}_{\mathrm{o}}(1-\mathrm{r})
$$

where $\mathrm{K}=$ adsorption coefficient of $\mathrm{NO}_{\mathrm{X}}$ on the catalyst.

The latter kinetic relationship more accurately predicts the space velocity (and hence catalyst volume) required to both remove $\mathrm{NO}_{\mathrm{X}}$ and minimize $\mathrm{NH}_{3}$ slip, especially at higher conversion levels. 
From a practical standpoint, the precise kinetic relationship is of little concern. What is important is the ratio $\mathrm{k} / \mathrm{k}_{\mathrm{o}}$, where $\mathrm{k}$ is the rate constant at a given time in the deactivation cycle and $\mathrm{k}_{\mathrm{o}}$ is the initial rate constant with fresh catalyst. This ratio, and thus catalytic activity, is determined by dividing the fractional $\mathrm{NO}_{\mathrm{X}}$ conversion at a given time by the conversion at time zero. The results for the SCR test program at Plant Crist are summarized in Figure 3, which shows the $\mathrm{k} / \mathrm{k}_{\mathrm{o}}$ ratio as a function of time. The relative activity begins at 1.0 at time zero and decreases to an average of about 0.8 at 12,000 hours (about 1.5 years).

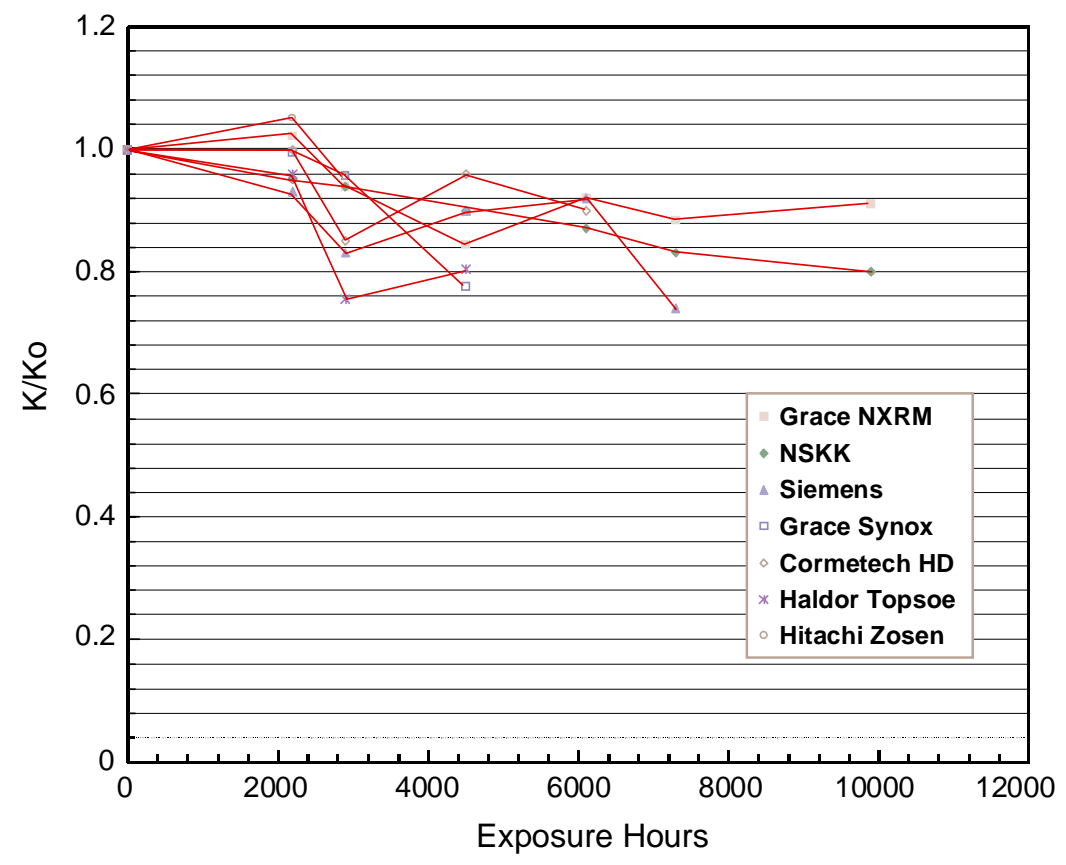

Figure 3. K/K $K_{0}$ Versus Exposure Time

\section{Parametric Studies}

The parametric studies investigated the effects of reactor operating temperature, $\mathrm{NH}_{3} / \mathrm{NO}_{\mathrm{X}}$ molar ratio, and space velocity on catalyst performance. Five sets of parametric data were obtained. The results are summarized in the following paragraphs. Some of the data refer to a single parametric study and are not necessarily representative of overall performance.

- $\quad$ Effect of Temperature on Ammonia Slip: The parametric tests covered the range of 620 to $750{ }^{\circ} \mathrm{F}$, with a design operating temperature of $700{ }^{\circ} \mathrm{F}$. Figure 4 shows that as temperature was increased while maintaining a constant $0.8 \mathrm{NH}_{3} / \mathrm{NO}_{\mathrm{X}}$ ratio, $\mathrm{NH}_{3}$ slip remained fairly constant at less than $5 \mathrm{ppm}$ for most of the catalysts. The exception was the Grace SNX catalyst - the $\mathrm{NH}_{3}$ slip was $10 \mathrm{ppm}$ at the lowest temperature, decreasing to the same level as the other catalysts at the higher temperatures. 


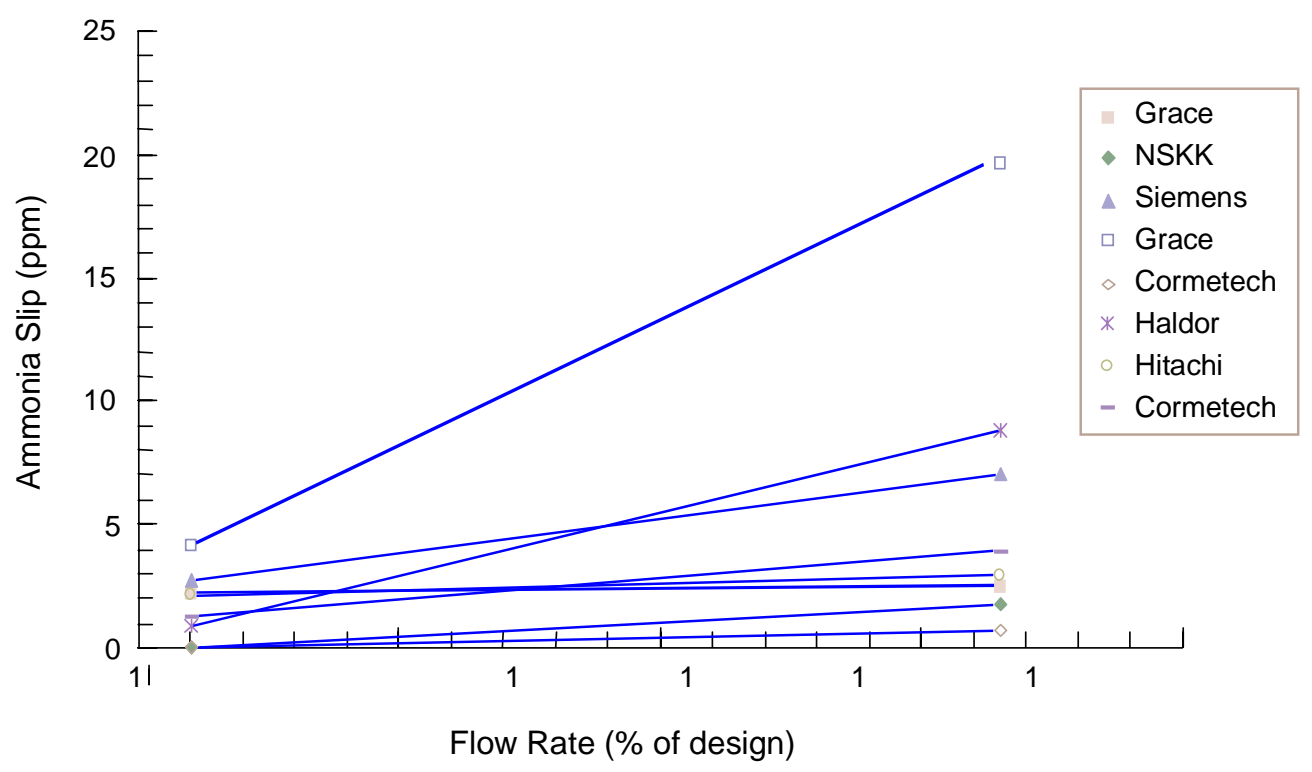

Figure 4. Ammonia Slip Versus Flow Rate

- $\quad$ Effect of $\mathbf{N H}_{3} / \mathrm{NO}_{\mathbf{x}}$ Ratio: The parametric tests covered a ratio range of 0.6 to 1.0 , with a design $\mathrm{NH}_{3} / \mathrm{NO}_{\mathrm{X}}$ molar ratio of 0.8. The results are shown in Figure 5. Except for one catalyst, $\mathrm{NH}_{3}$ slip remained constant at about $2 \mathrm{ppm}$ at low levels of the $\mathrm{NH}_{3} / \mathrm{NO}_{\mathrm{X}}$ ratio, increasing dramatically above a ratio of about 0.9 .

- $\quad$ Effect of Space Velocity: The effect of space velocity on $\mathrm{NH}_{3}$ slip is shown in Figure 6 . At an operating temperature of $700{ }^{\circ} \mathrm{F}$ and an $\mathrm{NH}_{3} / \mathrm{NO}_{\mathrm{X}}$ ratio of 0.8 , increasing the gas flow rate (and hence the space velocity) from 100 to 150 percent of the design value resulted in a fairly constant $\mathrm{NH}_{3}$ slip of less than $5 \mathrm{ppm}$ for three of the catalysts. $\mathrm{NH}_{3}$ slip increased to significantly greater than $5 \mathrm{ppm}$ for the other three catalysts studied in this part of the test program.

- $\quad$ Effect of Temperature on $\mathrm{SO}_{2}$ Oxidation: Figure 7 shows that as the temperature was increased, the rate of $\mathrm{SO}_{2}$ oxidation was fairly constant at less than 0.2 percent for two of the catalysts, while increasing to varying degrees for the other catalysts. 


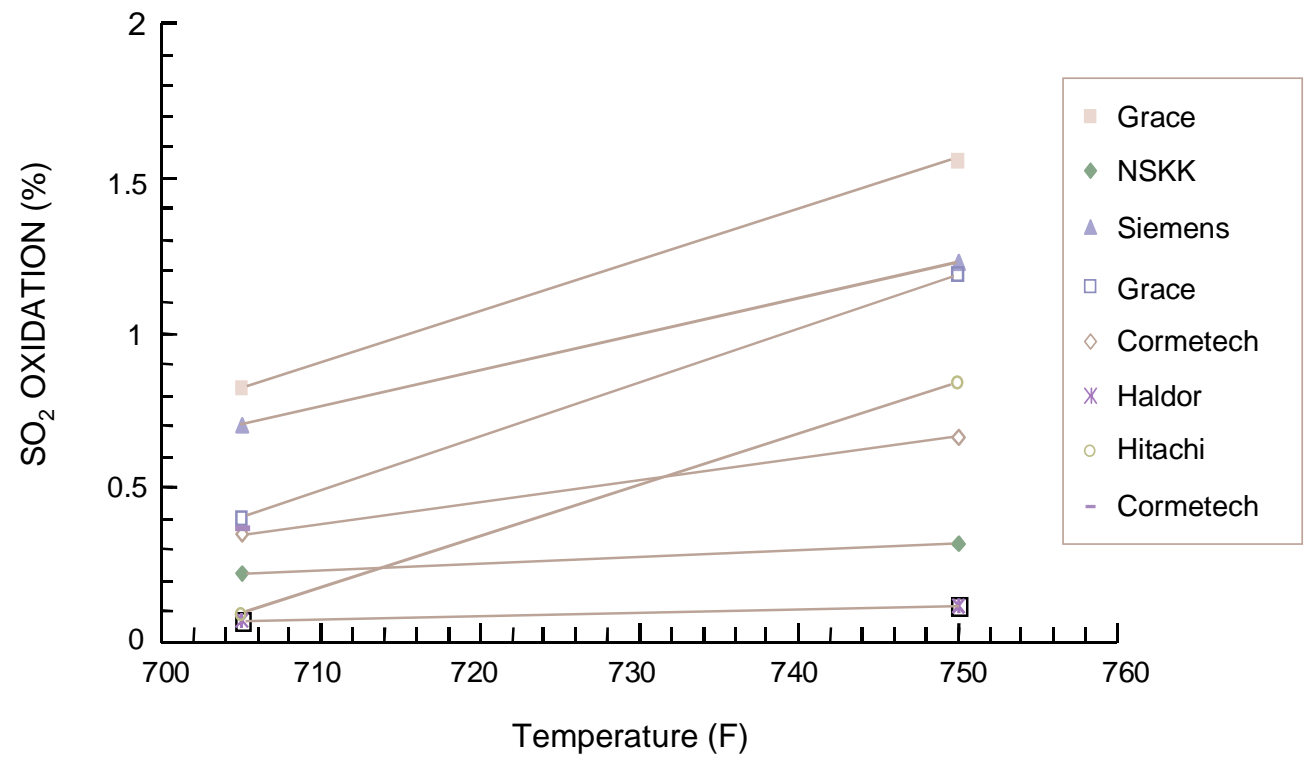

Figure 5. $\mathrm{SO}_{2}$ Oxidation Versus Temperature

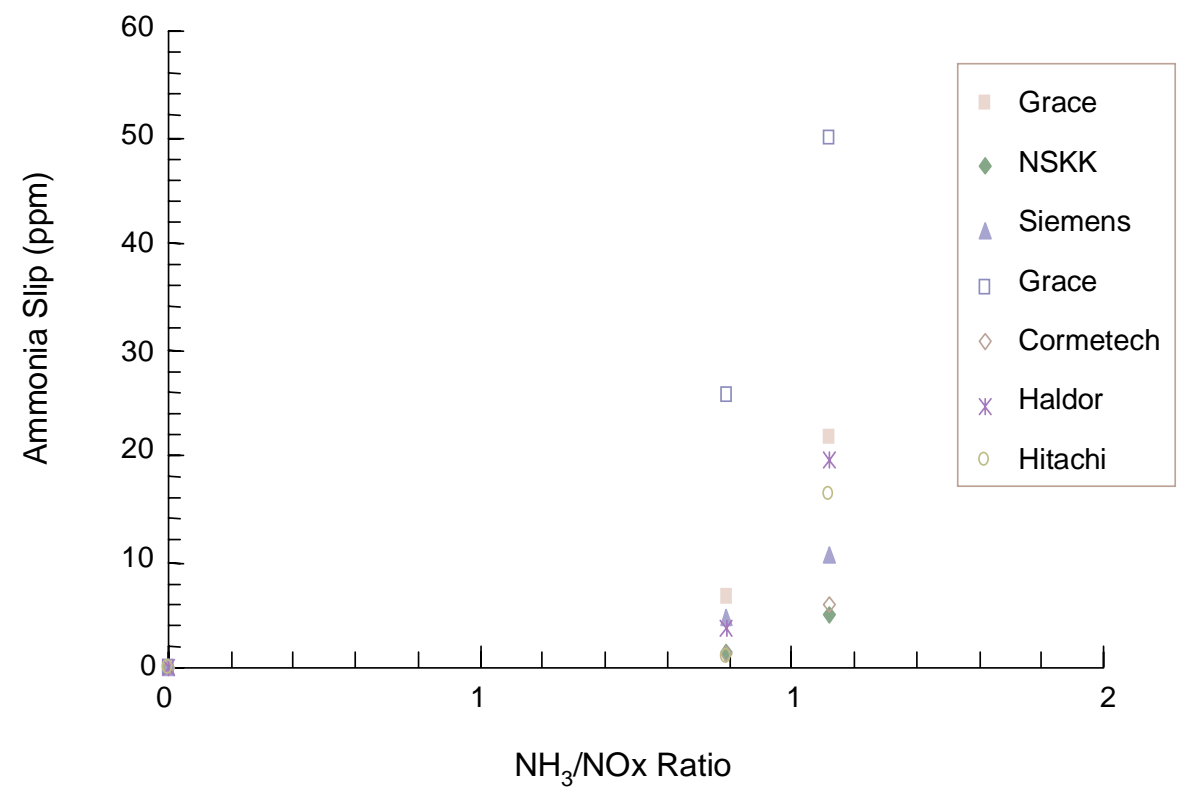

Figure 6. Ammonia Slip Versus $\mathrm{NH}_{3} / \mathrm{NO}_{\mathrm{x}}$ Ratio 


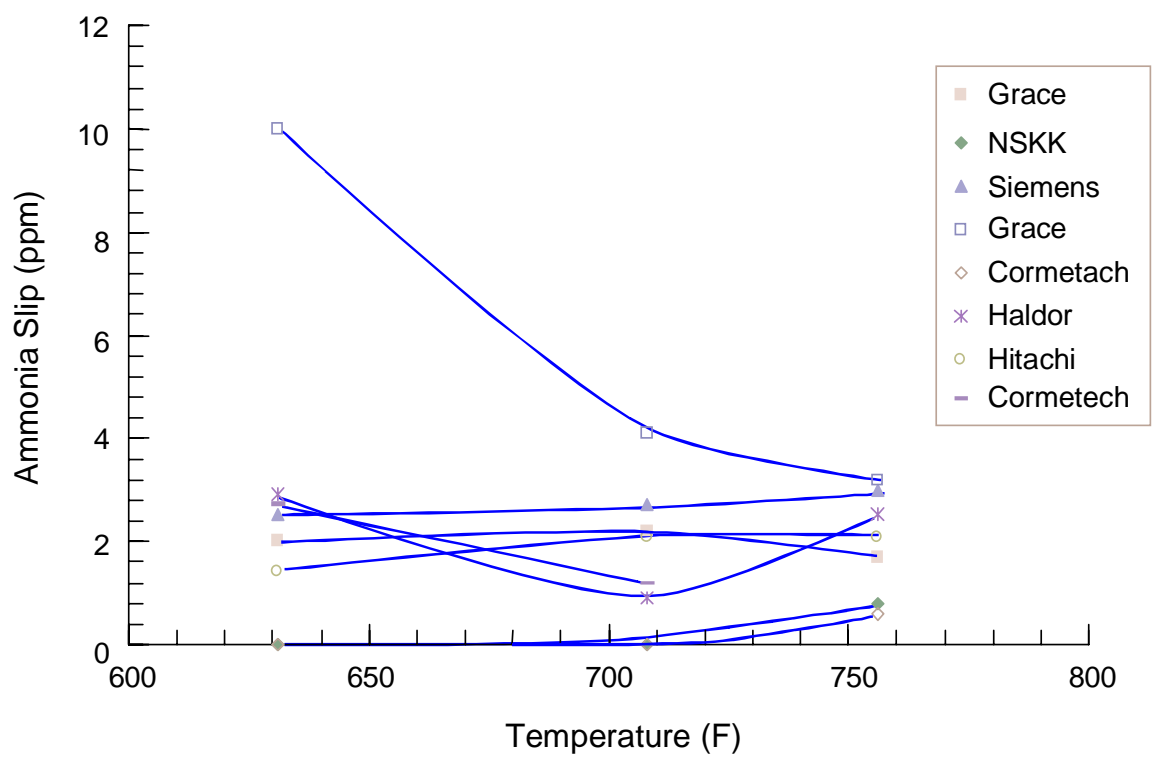

Figure 7. Ammonia Slip Versus Temperature

\section{Significance of Test Results}

The test data show that the SCR process can achieve high levels of $\mathrm{NO}_{\mathrm{X}}$ reduction while meeting acceptable $\mathrm{NH}_{3}$ slip levels over an extended period of operation (at least 2 years). In practice, SCR reactors are designed not just to meet a specified $\mathrm{NO}_{\mathrm{X}}$ level at startup, but sufficient catalyst volume is provided to allow for catalyst deactivation. This is normal practice in the design of any catalytic reactor, and is not unique to SCR.

$\mathrm{NO}_{\mathrm{X}}$ reduction is controlled for the most part by the $\mathrm{NH}_{3} / \mathrm{NO}_{\mathrm{X}}$ ratio. Therefore, even with excess catalyst in the reactor, $\mathrm{NO}_{\mathrm{X}}$ reduction remains essentially constant over the life of the catalyst. Ammonia slip increases somewhat over time until it reaches the design limit, at which point fresh catalyst is added. In this study, a high $\mathrm{NH}_{3}$ slip was observed at high levels of $\mathrm{NO}_{\mathrm{X}}$ reduction, very likely resulting from the difficulty in precisely measuring and controlling $\mathrm{NH}_{3}$ flow as well as the maldistribution (i.e., poor mixing) of $\mathrm{NH}_{3}$ and $\mathrm{NO}_{\mathrm{X}}$. Both issues become critical when operating at $\mathrm{NH}_{3} / \mathrm{NO}_{\mathrm{X}}$ ratios that approaches 1.0.

$\mathrm{SO}_{2}$ oxidation is much more temperature sensitive than $\mathrm{NO}_{\mathrm{X}}$ reduction. It can be minimized by controlling operating temperature, and is a function of catalyst formulation by the vendor. The optimum temperature will vary from catalyst to catalyst. 


\section{III.4 Boiler Impacts}

Operation of the SCR test unit, which treated a slipstream of flue gas downstream of the boiler, had no effect on boiler performance. In commercial practice, the presence of an SCR unit can affect boiler operation insofar as rate of ramping [what is this?] is concerned, since careful temperature control must be maintained at all times.

\section{III.5 Commercialization of the Technology}

\section{Current Status}

With the completion of the SCR test program at Plant Crist, the experimental facility was dismantled. In view of present and future environmental regulations, several U.S. companies have decided to use SCR on coal-fired utility boilers.

At present, there are six such installations, summarized in Table 5. One of these units, Birchwood, is an independent power producer jointly owned by Southern Energy, Inc. (SEI) and Cogentrix. SEI is a non-regulated subsidiary of Southern Company. The Birchwood SCR design considered data and operational lessons learned from the test program at Plant Crist as valuable input for specifying the process equipment. Since all of the U.S. installations are relatively new, there has not been sufficient time to evaluate long-term performance, particularly with respect to catalyst deactivation. All of the boilers operate on low- to medium-sulfur coals; five of the SCR units are associated with new plants, and one is a retrofit. All of the units are hot-side, high-dust installations.

The U.S. SCR units are achieving $\mathrm{NO}_{\mathrm{X}}$ reductions ranging from 56 to 71 percent, depending on the uncontrolled $\mathrm{NO}_{\mathrm{X}}$ concentration and the desired level of $\mathrm{NO}_{\mathrm{X}}$ in the stack gas. With the exception of one unit that appears to have initially contained insufficient catalyst, there have been few problems in meeting $\mathrm{NH}_{3}$ slip requirements, and catalyst deactivation has proceeded as predicted from the Plant Crist test data. The poorly performing unit initially experienced frequent plugging of the air preheater surfaces downstream of the SCR reactor. This problem was remedied by installing additional catalyst, which brought performance to the desired level. In general, the plant staff and management at each facility are pleased with the SCR operation, although at least some periodic washing of APHs has been necessary.

\section{Future Work}

Although SCR is now being used on coal-fired boilers in the United States, it is expected that design improvements will be made as operating experience is gained. SCR appears to be applicable to all types of boilers. The degree to which SCR will be incorporated in new or future retrofit applications will depend on the severity of $\mathrm{NO}_{\mathrm{X}}$ control standards yet to be promulgated. 
Table 5. Commercial SCR Installations on Coal-Fired Utility Boilers in the U.S.

\begin{tabular}{|c|c|c|c|c|c|c|}
\hline Plant & Birchwood & Stanton (Unit 2) & Carneys Point & Logan & Indiantown & Merrimack (Unit 2) \\
\hline $\begin{array}{l}\text { Owner/ } \\
\text { Operator }\end{array}$ & $\begin{array}{l}\text { SEI } \% \\
\text { Cogentrix }\end{array}$ & $\begin{array}{l}\text { Orlando Utilities } \\
\text { Commission }\end{array}$ & USGen $^{b}$ & USGen $^{b}$ & USGen $^{b}$ & Public Service of NH \\
\hline Location & $\begin{array}{l}\text { King George } \\
\text { County VA }\end{array}$ & Orlando FL & $\begin{array}{l}\text { Carneys Point } \\
\text { NJ }\end{array}$ & Swedesboro NJ & Indiantown FL & Concord NH \\
\hline $\begin{array}{l}\text { Capacity, MWe } \\
\text { (net) }\end{array}$ & 220 & 425 & 260 & 225 & 330 & 330 \\
\hline $\begin{array}{l}\text { Export Steam, } \\
\mathrm{lb} / \mathrm{hr}\end{array}$ & 75,000 & -- & $1,000,000$ & 50,000 & 125,000 & -- \\
\hline Steam Host & $\begin{array}{l}\text { Dominion } \\
\text { Growers }\end{array}$ & -- & DuPont & Monsanto & Caulkins Citrus & -- \\
\hline Coal Source & WV & KY & $\mathrm{PA}$ & wV & KY & $?$ \\
\hline Coal Sulfur, wt $\%$ & 1.0 & $1.1-1.2$ & $<2.0$ & $<1.5$ & 0.8 & 1.5 \\
\hline Boiler Mfg & $\mathrm{ABB} / \mathrm{CE}$ & $\mathrm{B} \& \mathrm{~W}$ & $\mathrm{~F} / \mathrm{W}$ & $\mathrm{F} / \mathrm{W}$ & $\mathrm{F} / \mathrm{W}$ & $\mathrm{B} \& \mathrm{~W} ?$ \\
\hline Boiler Type & $\mathrm{T}$-fired & Wall-fired & Wall-fired & Wall-fired & Wall-fired & Wet bottom \\
\hline Burner Type $^{c}$ & LNB/OFA & LNB/OFA & LNB/OFA & LNB/OFA & LNB/OFA & Cyclone \\
\hline SCR Installation & $\begin{array}{l}\text { Hot side, high } \\
\text { dust }\end{array}$ & Hot side, high dust & $\begin{array}{l}\text { Hot side, high } \\
\text { dust }\end{array}$ & $\begin{array}{l}\text { Hot side, high } \\
\text { dust }\end{array}$ & $\begin{array}{l}\text { Hot side, high } \\
\text { dust }\end{array}$ & Hot side, high dust \\
\hline SCR Catalyst Mfg & Siemens & Siemens & $\mathrm{IHI}^{\mathrm{d}}$ & Siemens & Siemens & Siemens \\
\hline Catalyst Type & Plate & Plate & Honeycomb & Plate & Plate & Plate \\
\hline $\begin{array}{l}\text { SCR Inlet } \mathrm{NO}_{\mathrm{X}} \\
\mathrm{lb} / 10^{6} \mathrm{Btu}\end{array}$ & 0.17 & 0.32 & 0.32 & 0.35 & 0.25 & 2.66 \\
\hline $\begin{array}{l}\text { SCR Outlet } \mathrm{NO}_{\mathrm{x}}, \\
\mathrm{lb} / 10^{6} \mathrm{Btu}\end{array}$ & 0.075 & 0.17 & 0.13 & 0.14 & 0.15 & 0.77 \\
\hline $\mathrm{NO}_{\mathrm{x}}$ Reduction, $\%$ & 56 & 47 & 59 & 60 & 40 & 71 \\
\hline $\mathrm{NH}_{3}$ Slip, ppm & $<5$ & 2 & $<5$ & $<5$ & $<5$ & $<2$ \\
\hline $\begin{array}{l}\text { SCR Pressure } \\
\text { Drop, in. } \mathrm{H}_{2} \mathrm{O}\end{array}$ & 6 & $?$ & $<1.0$ & 0.8 & $\begin{array}{l}\text { Not } \\
\text { measured }\end{array}$ & $\begin{array}{l}\text { Not } \\
\text { measured }\end{array}$ \\
\hline $\begin{array}{l}\text { Date SCR } \\
\text { Commercial }\end{array}$ & $11 / 96$ & $6 / 96$ & $3 / 94$ & $9 / 94$ & $12 / 95$ & $5 / 95$ \\
\hline $\begin{array}{l}\text { Carbon on Fly Ash, } \\
\text { wt } \%\end{array}$ & $?$ & $6-7$ & $\begin{array}{l}15-17 \\
(9-10) ?\end{array}$ & $18-22$ & $15-20$ & $-{ }_{--}$ \\
\hline SCR New/ Retrofit & New & New & New & New & New & Retrofit \\
\hline $\mathrm{NH}_{3}$ for $\mathrm{SCR}$ & Anhydrous & Anhydrous & Aqueous & Aqueous & Aqueous & Anhydrous \\
\hline
\end{tabular}

${ }^{\text {a }}$ Southern Energy, Inc.; ${ }^{\mathbf{b}}$ U.S. Generating Company, a Pacific Gas and Electric Company/Bechtel partnership;

${ }^{\mathrm{c}} \mathrm{LNB}=$ Low-NO $\mathrm{N}_{\mathrm{x}}$ burners; OFA = overfire air; ${ }^{\mathrm{d}}$ Ishikawajima-Harima Heavy Industries; ${ }^{\mathrm{e}}$ Fly ash recycled to boiler 


\section{Market Analysis}

\section{IV.1 Potential Markets}

The SCR process is applicable to all types of conventional coal-fired boilers, including stoker, cyclone, wall-fired and tangentially fired boilers. As an indication of the potential market for SCR in the U.S., Table 6 lists the boiler population in the Ozone Transport Assessment Group (OTAG) region.

Table 6. Boiler Population in the OTAG Region

\begin{tabular}{|l|c|c|}
\hline Boiler Type & Number of Units & Generating Capacity, MWe \\
\hline Wall-fired & 315 & 94,327 \\
\hline Tangentially fired & 315 & 112,000 \\
\hline Cyclone & 77 & 22,329 \\
\hline Cell-fired & 33 & 24,143 \\
\hline Wet-bottom & 23 & 4,712 \\
\hline Roof-fired & 29 & 3,111 \\
\hline Total & 792 & 260,622 \\
\hline
\end{tabular}

OTAG, which was created by EPA for the purpose of developing recommendations for ozone reduction, comprises 37 contiguous states, omitting the 11 westernmost states. Many boilers in the OTAG region are candidates for SCR, although regulations are still being formulated and many of these boilers may not be subject to $\mathrm{NO}_{\mathrm{X}}$ emissions limits stringent enough to require the use of SCR technology. In any given case, the economic viability of SCR will depend on retrofit difficulty and other site-specific factors.

The need for SCR will be dictated by power plant $\mathrm{NO}_{\mathrm{X}}$ emissions limits now being considered. LNBs, with or without overfire air (OFA) may not be able to meet the lower $\mathrm{NO}_{\mathrm{X}}$ target levels. Utilities subject to the most stringent requirements may be forced to use SCR, either alone or in conjunction with LNBs.

\section{IV.2 Economic Assessment of Utility Boiler Applications}

\section{SCR Costs - Southern Company Estimates}

Southern's final report includes economic estimates for the SCR process. The base case is a 250 MWe greenfield unit, using a projected process design for the $n^{\text {th }}$ plant, which incorporates 
improvements based on experience gained from the demonstration project. The boiler is either a wall-fired or tangentially fired unit, equipped with LNBs. The coal feed is assumed to contain 2.5 wt $\%$ sulfur. The design $\mathrm{NO}_{\mathrm{X}}$ concentration at the reactor inlet is $0.35 \mathrm{lb} / 10^{6} \mathrm{Btu}$. $\mathrm{NO}_{\mathrm{X}}$ reduction in the SCR unit is assumed to be 60 percent, yielding an outlet concentration of $0.14 \mathrm{lb} / 10^{6} \mathrm{Btu}$. Catalyst deactivation is assumed to be 20 percent at $16,000 \mathrm{hr}$; that is, the $\mathrm{k} / \mathrm{k}_{\mathrm{o}}$ ratio is 0.8 at that time. The catalyst price is $\$ 400 / \mathrm{cu} \mathrm{ft}$.

The estimated capital cost is $\$ 54 / \mathrm{kW}$. For a 30 -year project life, the levelized cost on a current dollar basis is 2.57 mills $/ \mathrm{kWh}$. This is equivalent to $\$ 2,500 /$ ton of $\mathrm{NO}_{\mathrm{X}}$ removed. On a constant dollar basis, the levelized cost is 1.85 mills $/ \mathrm{kWh}$, equivalent to $\$ 1,802 /$ ton of $\mathrm{NO}_{\mathrm{X}}$ removed. Table 7 summarizes the performance and cost data.

Table 7. Summary of Performance and Cost Data, 1996 Dollars

\begin{tabular}{|c|c|c|}
\hline & Units & Value \\
\hline $\begin{array}{l}\text { Coal Properties } \\
\text { Higher Heating Value (HHV) }\end{array}$ & Btu/lb & 12,500 \\
\hline $\begin{array}{r}\text { Power Plant Attributes With Controls } \\
\text { Plant Capacity, Net } \\
\text { Power Produced, Net } \\
\text { Capacity Factor } \\
\text { Coal Fed }\end{array}$ & $\begin{array}{c}\mathrm{MWe} \\
10^{9} \mathrm{kWh} / \mathrm{yr} \\
\% \\
10^{6} \text { tons } / \mathrm{yr}\end{array}$ & $\begin{array}{c}250 \\
1.34 \\
65 \\
0.54\end{array}$ \\
\hline $\begin{array}{r}\text { NO }_{\mathrm{x}} \text { Emissions Control Data } \\
\text { Removal Efficiency } \\
\text { Emissions Without SCR } \\
\text { Emissions With SCR } \\
\mathrm{NO}_{\mathrm{X}} \text { Removed }\end{array}$ & $\begin{array}{c}\% \\
\mathrm{lb} / 10^{6} \mathrm{Btu} \\
\mathrm{lb} / 10^{6} \mathrm{Btu} \\
\text { tons/yr }\end{array}$ & $\begin{array}{c}60 \\
0.35 \\
0.14 \\
1,374\end{array}$ \\
\hline Total Capital Requirement & $\$ / \mathrm{kW}$ & 54 \\
\hline
\end{tabular}

\begin{tabular}{|r|c|c|c|}
\hline & Levelization Factor (a) & mills/kWh & \$/ton NO \\
$\mathbf{x}$ Removed \\
\hline Levelized Cost, Current \$ & & & \\
Capital Charge & 0.150 & 1.50 & 1,464 \\
Fixed O\&M & 1.362 & 0.32 & 310 \\
Variable O\&M & 1.362 & $\underline{0.75}$ & $\underline{726}$ \\
Total & & $\mathbf{2 . 7 5}$ & $\mathbf{2 , 5 0 0}$ \\
\hline Levelized Cost, Constant \$ & & & \\
Capital Charge & 0.116 & 1.16 & 1,132 \\
Fixed O\&M & 1.000 & 0.23 & 228 \\
Variable O\&M & 1.000 & $\underline{0.46}$ & $\underline{442}$ \\
Total & & $\mathbf{1 . 8 5}$ & $\mathbf{1 , 8 0 2}$ \\
\hline
\end{tabular}


Obviously, the economics are highly dependent on a number of variables, including plant capacity, degree of $\mathrm{NO}_{\mathrm{X}}$ removal, and inlet $\mathrm{NO}_{\mathrm{X}}$ concentration. Southern's economic analysis includes the effects of these variables, summarized in Table 8 below. Levelized costs are on a current dollar basis.

Table 8. Effects of Variables on SCR Performance

\begin{tabular}{|c|c|c|c|}
\hline Capacity, MWe & 125 & 250 & 700 \\
\hline $\mathrm{NO}_{\mathrm{X}}$ Removal, \% & 60 & 60 & 60 \\
\hline Inlet $\mathrm{NO}_{\mathrm{X}}, \mathrm{lb} / 10^{6} \mathrm{Btu}$ & 0.35 & 0.35 & 0.35 \\
\hline Capital, \$/kW & 61 & 54 & 45 \\
\hline$\$ /$ ton $\mathrm{NO}_{\mathrm{X}}$ removed & 2811 & 2500 & 2165 \\
\hline Capacity, MWe & 250 & 250 & 250 \\
\hline NO $_{\mathrm{x}}$ Removal, \% & 40 & 60 & 80 \\
\hline Inlet $\mathrm{NO}_{\mathrm{X}}, \mathrm{lb} / 10^{6} \mathrm{Btu}$ & 0.35 & 0.35 & 0.35 \\
\hline Capital, \$/kW & 52 & 54 & 57 \\
\hline$\$ /$ ton $\mathrm{NO}_{\mathrm{X}}$ removed & 3502 & 2500 & 2036 \\
\hline Capacity, MWe & 250 & 250 & 250 \\
\hline $\mathrm{NO}_{\mathrm{X}}$ Removal, \% & 60 & 60 & 60 \\
\hline Inlet $\mathrm{NO}_{\mathrm{x}}, \mathrm{lb} / \mathbf{1 0}^{6} \mathrm{Btu}$ & 0.45 & 0.35 & 0.25 \\
\hline Capital, \$/kW & 54 & 54 & 54 \\
\hline$\$ /$ ton $\mathrm{NO}_{\mathrm{X}}$ removed & 1977 & 2500 & 3446 \\
\hline
\end{tabular}

At a given plant capacity, levelized costs (\$/ton of $\mathrm{NO}_{\mathrm{X}}$ removed) decrease with an increasing $\mathrm{NO}_{\mathrm{X}}$ removal rate and increasing initial $\mathrm{NO}_{\mathrm{X}}$ concentration, such as would occur in situations where SCR is used on boilers with the highest uncontrolled $\mathrm{NO}_{\mathrm{X}}$ levels and without combustion modification. Not shown in the above table is the effect of catalyst deactivation. Longer catalyst life, reduced catalyst prices, or both would reduce costs. Retrofit costs can be significantly greater, especially in cases involving difficult reactor siting and duct arrangements, new fans, and balanced draft conversions. In one case, the estimated capital cost was $\$ 130 / \mathrm{kW}$, representing $\$ 65 / \mathrm{kW}$ for the SCR unit and $\$ 65 / \mathrm{kW}$ for conversion to balanced draft operation.

Because of the relatively high capital costs involved, some companies are investigating innovative business arrangements for implementing SCR projects. 


\section{SCR Costs - Commercial Installations}

Costs for recent U.S. commercial applications of SCR have been obtained for two power plants: the Stanton Energy Center (Unit 2) in Florida, and the Merrimack (Unit 2) in New Hampshire. At Stanton, which was a new installation having a capacity of 425 MWe net and a $\mathrm{NO}_{\mathrm{X}}$ removal efficiency of 47 percent, the capital cost was $\$ 14$ million, which is equivalent to $\$ 33 / \mathrm{kW}$. At Merrimack, which was a retrofit installation having a capacity of 330 MWe net and a $\mathrm{NO}_{\mathrm{X}}$ removal efficiency of 71 percent, the capital cost was $\$ 18.5$ million, which is equivalent to $\$ 56 / \mathrm{kW}$. To compare these capital costs with those developed by Southern would require more detailed information on the scope of work involved. For both plants, operating costs consist primarily of $\mathrm{NH}_{3}$ reagent expense and catalyst replacement. According to management at those two plants, additional labor or maintenance costs incurred by the SCR units are minimal.

\section{Comparison With Other Technologies}

$\mathrm{NO}_{\mathrm{X}}$ reduction sufficient to meet Title IV requirements is currently being achieved by combustion modification, which includes LNBs and fuel reburning. To reach deeper reductions in $\mathrm{NO}_{\mathrm{X}}$ emissions as proposed in the new Title I regulations may require post-combustion processes, which include SCR and selective non-catalytic reduction (SNCR). Since SNCR does not require a catalyst, it is considerably less expensive than SCR. However, typical demonstrated $\mathrm{NO}_{\mathrm{x}}$ removal for SNCR ranges from about 25 to 40 percent, which is much lower than with SCR. In addition, some experience has shown that SNCR applications are limited to smaller boilers because of difficulties in achieving uniform distribution of reagent in the flue gas stream. Numerous control problems have arisen especially where loads fluctuate. Therefore, SCR may be preferred over SNCR in some situations. Hybrid processes, using SNCR followed by SCR, have the potential for operating flexibility at lower overall cost. Such configurations need to be evaluated on a case-by-case basis. 


\section{Conclusions}

The SCR demonstration project was successful: all objectives were met. All eight catalysts in the test program met design specifications, providing at least 80-percent $\mathrm{NO}_{\mathrm{X}}$ removal at an $\mathrm{NH}_{3}$ slip of 5 ppm or less. Although the catalysts varied somewhat in operating characteristics, such as activity and pressure drop, no one catalyst was found to be superior. Catalyst deactivation proceeded as expected based on European and Japanese experience, with an average decrease in activity of 20 percent over a 2-year period. Although no unusual deactivation effects could be attributed to the use of high-sulfur U.S. coals containing typical concentrations of metals such as arsenic, there is uncertainty regarding the required frequency of catalyst replacement. Both plate and honeycomb catalysts performed satisfactorily.

There was significant variation in the rate of oxidation of $\mathrm{SO}_{2}$ to $\mathrm{SO}_{3}$ among the catalysts tested. Sufficient amounts of $\left(\mathrm{NH}_{4}\right)_{2} \mathrm{SO}_{4}$ and $\mathrm{NH}_{4} \mathrm{HSO}_{4}$ were formed to result in corrosion and plugging of the APHs, requiring periodic washing. The overall stability of the pressure drop across the catalysts over time indicated that the soot-blowing procedures used in the test program were satisfactory. Performance comparisons between high-dust and low-dust reactor configurations were inconclusive because of problems associated with the design of the low-dust reactor.

A commercial scale SCR unit can be installed for about $\$ 54 / \mathrm{kW}$ in a new plant. Retrofit costs could be significantly higher. Six commercial SCR units are operating on low- and mediumsulfur coals in the United States. A significant market for SCR exists in the United States, especially in light of increasingly stringent limitations on $\mathrm{NO}_{\mathrm{X}}$ emissions. Design improvements can be expected as operating experience is gained, and application to other boilers can be anticipated. 


\section{Abbreviations and Acronyms}

$\begin{array}{ll}\text { APH } & \text { air preheater } \\ \text { BACT } & \text { best available control technologies } \\ \text { CAAA } & \text { Clean Air Act Amendments } \\ \text { CCT } & \text { Clean Coal Technology Program } \\ \text { DOE } & \text { U.S. Department of Energy } \\ \text { EPA } & \text { U.S. Environmental Protection Agency } \\ \text { EPRI } & \text { formerly the Electric Power Research Institute } \\ \text { ESP } & \text { electrostatic precipitator } \\ \text { LNBs } & \text { low NO }{ }_{x} \text { burners } \\ \text { NAAQS } & \text { National Ambient Air Quality Standards } \\ \text { NH } & \text { ammonia } \\ \left.\text { NH }_{4}\right)_{2} \text { SO }_{4} & \text { ammonium sulfate } \\ \text { NH } & \text { asSO } \\ \text { NOTR } & \text { ammonium bisulfate } \\ \text { NO } & \text { Northeast Ozone Transport Region } \\ \text { NSPS } & \text { nitrogen oxides } \\ \text { OFA } & \text { New Source Performance Standards } \\ \text { OTAG } & \text { Oefine, see section IV.1, page 25 } \\ \text { RACT } & \text { reasonably available control technology } \\ \text { SCR } & \text { selective catalytic reduction } \\ \text { SNCR } & \text { selective non-catalytic reduction } \\ \text { SEI } & \text { Southern Energy Inc. } \\ \text { SIP } & \text { State Implementation Plan } \\ \text { SO } & \text { sulfur dioxide } \\ \text { SO } & \text { sulfur trioxide } \\ \text { T-fired } & \text { tangentially fired } \\ \text { VOCs } & \text { volatile organic compounds } \\ \end{array}$




\section{References}

Baldwin, A.L., D.N. Smith, A.N. Mann, H.G. McIlvried, and S.N. Rao. January 1995. Is Selective Catalytic Reduction (SCR) an Attractive Option for $\mathrm{NO}_{\mathrm{x}}$ Control in Coal-Fired Power Plants?, presented at Air \& Waste Management Association Conference, Tempe, Arizona, January 1995.

Cho, S.M. January 1994. Properly Apply Selective Catalytic Reduction for $\mathrm{NO}_{\mathrm{x}}$ Removal, Chemical Engineering Progress, pp. 39-45.

Rao, S.N., H.G. McIlvried, and A.N. Mann. September 1994. Evaluation of $N_{x}$ Removal Technologies, Volume 1: Selective Catalytic Reduction (Revision 2), Burns and Roe Services Corporation.

Radian Corporation. September 1996. Plant Crist Environmental Monitoring Program, Final Report, Radian Corporation.

Southern Company Services. April 1990. Demonstration of Selective Catalytic Reduction (SCR) Technology for the Control of Nitrogen Oxide $\left(N_{X}\right)$ Emissions from High-Sulfur, Coal-Fired Boilers, Comprehensive Report to Congress, Clean Coal Technology Program, proposed by Southern Company Services, Inc.

Southern Company Services. October 1996. Demonstration of Selective Catalytic Reduction (SCR) Technology for the Control of Nitrogen Oxide $\left(N O_{x}\right)$ Emissions from High-Sulfur CoalFired Boilers, Final Report, Southern Company Services. 


\section{Bibliography}

Baldwin, A.L., D.N. Smith, A.N. Mann, H.G. Mcllvried, and D.L. Russell. June 1997. The Role of the U.S. Clean Coal Technology Program in Implementing the Objectives of the Joint CanadaU.S. Acid Rain Mitigation Initiative, presented at the Air \& Waste Management Association Annual Meeting, Toronto, Canada, June 1997.

Environmental Protection Agency. October 1996. Performance of Selective Catalytic Reduction Technology at Electric Utility Boilers in the United States, Germany and Sweden, Draft Report, EPA Office of Air and Radiation, Acid Rain Program.

Healy, E.C., J.D. Maxwell, and W.S. Hinton. September 1996. Economic Evaluation of Commercial-Scale SCR Applications for Utility Boilers, Southern Company Services.

Hinton, W.S., J.D. Maxwell, and A.L. Baldwin. September 1995. Demonstration of Selective Catalytic Reduction (SCR) Technology for the Control of Nitrogen Oxides $\left(\mathrm{NO}_{x}\right)$ Emissions from High- Sulfur Coal-Fired Utility Boilers at Plant Crist SCR Test Facility, Southern Company Services, presented at the Fourth Annual Clean Coal Technology Conference, Denver, Colorado, September 1995.

Hinton, W.S., J.D. Maxwell, E.C. Healy, and R.R. Hardman. August 1996. Demonstration of SCR Technology for the Control of $\mathrm{NO}_{x}$ Emissions from High-Sulfur Coal-Fired Utility Boilers, Southern Company Services, presented at EPRI Workshop, Cincinnati, Ohio, August 1996.

Hinton, W.S., J.D. Maxwell, E.C. Healy, R.R. Hardman, and A.L. Baldwin. January 1997. Demonstration of SCR Technology for the Control of $\mathrm{NO}_{\mathrm{x}}$ Emissions from High-Sulfur CoalFired Utility Boilers, presented at the Fifth Annual Clean Coal Technology Conference, Tampa, Florida, January 1997.

Hinton, W.S., C.A. Powell, and J.D. Maxwell. September 1993. Demonstration of Selective Catalytic Reduction Technology for the Control of Nitrogen Oxide Emissions from High-Sulfur, Coal-Fired Boilers, Southern Company Services, presented at the Second Annual Clean Coal Technology Conference, Atlanta, Georgia, September 1993.

Hinton, W.S., C.A. Powell, and J.D. Maxwell. September 1994. Demonstration of Selective Catalytic Reduction (SCR) Technology for the Control of Nitrogen Oxides $\left(\mathrm{NO}_{\mathrm{x}}\right)$ Emissions from High-Sulfur, Coal-Fired Boilers at Plant Crist SCR Test Facility, Southern Company Services, presented at the Third Annual Clean Coal Technology Conference, Chicago, Illinois, September 1994.

Maxwell, J.W., and Baldwin, A.L. September 1992. Demonstration of Selective Catalytic Reduction (SCR) Technology for the Control of Nitrogen Oxide $\left(\mathrm{NO}_{\mathrm{x}}\right)$ Emissions from HighSulfur, Coal-Fired Boilers, presented at the First Annual Clean Coal Technology Conference, Cleveland, Ohio, September 1992. 